Article

\title{
Spruce Bark-A Source of Polyphenolic Compounds: Optimizing the Operating Conditions of Supercritical Carbon Dioxide Extraction
}

\author{
Petra Strižincová ${ }^{1, *}$, Aleš Ház ${ }^{1}$,, Zuzana Burčová ${ }^{2}$, Jozef Feranc ${ }^{3}$, František Kreps ${ }^{2}$, \\ Igor Šurina ${ }^{1}$ (D) and Michal Jablonský ${ }^{1}$ \\ 1 Institute of Natural and Synthetic Polymers, Department of Wood, Pulp and Paper, Faculty of Chemical and Food \\ Technology, Slovak University of Technology in Bratislava, Radlinského 9, SK-812 37 Bratislava, Slovakia; \\ ales.haz@stuba.sk (A.H.); igor.surina@stuba.sk (I.S.); michal.jablonsky@stuba.sk (M.J.) \\ 2 Institute of Food Science and Nutrition, Faculty of Chemical and Food Technology, Slovak University \\ of Technology in Bratislava, Radlinského 9, SK-812 37 Bratislava, Slovakia; zuzana.burcova@stuba.sk (Z.B.); \\ frantisek.kreps@stuba.sk (F.K.) \\ 3 Institute of Natural and Synthetic Polymers, Department of Plastics and Rubber, Faculty of Chemical and Food \\ Technology, Slovak University of Technology in Bratislava, Radlinského 9, SK-812 37 Bratislava, Slovakia; \\ jozef.feranc@stuba.sk \\ * Correspondence: petra.strizincova@stuba.sk
}

Received: 15 October 2019; Accepted: 6 November 2019; Published: 8 November 2019 updates

\begin{abstract}
The present study described the optimization of the extraction process with carbon dioxide in supercritical state for obtaining extractives, especially polyphenols from softwood bark, Norway spruce (Picea abies (L.) Karst.). Using a full $2^{3}$ factorial design of experiments, the effect of varying the working parameters on the yield of extractives was studied for the following ranges: temperature $40-100{ }^{\circ} \mathrm{C}$, pressure $1050-9000 \mathrm{psi}(7.2-62 \mathrm{MPa})$, and concentration of EtOH/water co-solvent mixture $40-96.6 \%$. In addition, total phenolics content and the antioxidant capacity of the spruce bark extract were determined. The optimum operating conditions for the yield of extractives were identified as $73{ }^{\circ} \mathrm{C}, 6465 \mathrm{psi}(44.5 \mathrm{MPa})$, and $58 \% \mathrm{EtOH} /$ water cosolvent concentration for a yield of $8.92 \%$. The optimum conditions for achieving a total phenolics content of $13.89 \mathrm{mg}$ gallic acid equivalent (GAE)/g dry extract were determined as: $45^{\circ} \mathrm{C}, 1050 \mathrm{psi}(7.2 \mathrm{MPa})$, and $96.6 \%$ $\mathrm{EtOH} /$ water mixture.
\end{abstract}

Keywords: supercritical extraction; polyphenolic compounds; extractives; experimental design optimization; spruce bark

\section{Introduction}

Today, the increasing consumption of nonrenewable resources, such as oil, coal, and natural gas, is a worldwide problem. The supplies of these resources are limited and are expected to run out in a few years. The supply of natural gas is estimated to last for about 65 more years, while oil supply is expected to last 40 years and coal is expected to last 300 years. One of the solutions to avoid the exhaustion of fossil fuel is to find a sustainable method, using abundant resources, to obtain equivalent products-materials and chemicals made from lignocellulose materials. Currently, significant emphasis is placed on maximizing the exploitation of industrial biomass waste, such as tree bark, turning it into value-added products. Tree bark is gaining attention due to its unique composition and content of valuable biochemicals, i.e., extractives, and also as an economically and ecologically significant material due its biodegradability, renewability, low cost, and large potential availability [1]. Unfortunately, the wood processing industry does not currently use tree bark to its 
full potential. Most of the bark resulting from the wood, pulp, and paper industries is burnt for the production of energy and heat. The remaining part of the bark is used in traditional applications, e.g., as mulching material, in horticulture, and as ornamental bark [2,3].

The Slovak forest covers $41.1 \%$ of the country's land area. The most abundant tree species in the Slovak republic include European beech (33.5\%), Norway spruce (23.1\%), sessile/English oak (10.6\%), and Scots pine (6.8\%) [1]. The industries log, on average, $5 \mathrm{Mm}^{3}$ of Norway spruce per year, producing $0.5 \mathrm{Mm}^{3}$ of spruce bark, considering a $10-12 \%$ volumetric bark content in logs. Since approximately $32 \%$ of the bark represents extractives, the valorization of this byproduct is highly important [4]. Such exploitation of the bark consists in extracting bark components, thus achieving higher value bio-based materials and bioactive compounds that could be used in a variety of pharmaceutical, chemical, cosmetic, and food applications. At the end of its lifecycle, bark could be combusted for generating electricity [5-8].

Extractives are derived from the metabolic processes of plants and include a wide range of phytochemicals with different physical properties. Spruce bark is rich in extractives, such as phenolic compounds, that make up one of the major families of secondary metabolites. In general, more than 8000 phenolic structures are currently known [9], including a diverse group of compounds of soluble phenolics such as flavonoids, phenolic acids, stilbenes, and nonsoluble compounds, such as lignins and condensed tannins [10]. Several studies have reported that these chemical compounds have a wide range of bioactive properties, such as cytotoxic, antibacterial, repellent, fungicidal, antimycotic, antitumor, anti-inflammatory, antiviral, antimalarial, antimutagenic, and growth-inhibiting effects [11-17]. The work of Jablonsky et al. [13] summarized the properties of 237 compounds extracted from coniferous bark and reported in various studies. The following activities have been established for the substances extracted from bark: Cytotoxic (25 identified substances), antioxidant (26 substances), fungicidal (20 substances), antibacterial (42 substances), anti-inflammatory (10 substances), antimutagenic (5 substances), pharmacokinetic (5 substances), pheromone (10 substances), and inhibiting (22 substances) [13]. For obtaining specific bioactive compounds with the desired properties, it is essential to find suitable experimental conditions of isolation, since the extraction parameters determine a qualitative and quantitative representation of individual components. The isolation method can provide a simple way to separate the desired extractives from components of the matrix while keeping the original matrix usable for ultimate energy production. Based on the literature survey, the following extraction methods have been investigated for phytochemicals: Solvent extraction ultrasound-assisted extraction (UAE) [18,19], supercritical fluid extraction (SFE) [20,21], microwave-assisted extraction (MAE) [22,23], accelerated solvent extraction (ASE) [24], and subcritical water extraction (SWE) [25,26].

The aim of this study was to optimize the working parameters (i.e., temperature, pressure, and cosolvent concentration) for isolating extractives from spruce bark using supercritical extraction with carbon dioxide $\left(\mathrm{CO}_{2}\right)$.

The method of experimental design (DOE) was applied for statistical evaluation of the measurements. These measurements were used for optimizing the extraction conditions to achieve the maximum extraction yield from spruce bark. In addition, the isolated extractives were determined to evaluate their total phenolics content and their antioxidant capacity. Based on the findings of this study, we concluded that the selected extraction conditions (pressure, temperature, and concentration of the solvent), as well as their interaction with other parameters, have a significant impact on the monitored properties.

\section{Results and Discussion}

In this study, the method of experimental design was applied to investigate the effects of temperature, pressure and cosolvent concentration on the yield of extractives. In addition, total phenolics content and the antioxidant capacity was assessed. A full $2^{3}$ factorial design of experiments was performed for a comprehensive description of the selected physical parameters affecting the extraction process. The effects of the selected variables were determined in the following ranges: 
temperature $\mathrm{t}=40-100{ }^{\circ} \mathrm{C}$, cosolvent concentration $\mathrm{c}=40-96.6 \%$ and pressure $\mathrm{p}=1050-9000 \mathrm{psi}$ (7.2-62 MPa). The extraction time (50 $\mathrm{min})$, particle size $(1-1.4 \mathrm{~mm})$ and the ratio between the raw material and cosolvent $(1: 5(w / v))$ were kept constant during the experimental procedures. The complete DOE consisted of twenty combinations, including six replicates of the center point for the reported standard deviation from the overall mean. The levels of the independent variables under investigation are listed in Tables 1 and 2.

The method of experimental design mathematically evaluates of measurement using analysis of variance. The analysis of variance (ANOVA) was employed to assess the statistically significant factors. The mathematical relationship of each response to the selected variables is approximated by the general quadratic polynomial shown in Equation (1):

$$
Y=\beta_{0}+\sum \beta_{j} X_{j}+\sum \beta_{j j} X_{j}^{2}+\sum \beta_{j k} X_{j} X_{k}
$$

where $Y$ is the response, $\beta_{0}$ is a constant, $\beta_{j}$ is the linear coefficient, $\beta_{j k}$ is the interaction or crossed coefficient, and $\beta_{\mathrm{jj}}$ is the quadratic coefficient [27].

The output of the method of experimental design is a system of regression equations that are used for optimization of the system. Statistical and analysis data were evaluated using the STATIS software [27] and for optimisation of yield of extractives was used subprogram Solver, MS Excel.

First of all, the effect of temperature was examined between $40-100{ }^{\circ} \mathrm{C}$. The minimum extraction temperature $\left(\mathrm{T}_{\min }=40{ }^{\circ} \mathrm{C}\right)$ was defined in the vicinity of the critical point of carbon dioxide $\left(\mathrm{T}_{\mathrm{C}} \mathrm{CO}_{2}=31.3{ }^{\circ} \mathrm{C}\right)$ and the maximum temperature was set at $\mathrm{T}_{\max }=100{ }^{\circ} \mathrm{C}$ to avoid possible degradation of thermally labile compounds, which occurs during heating [28,29]. Ethanol was used as co-solvent in various concentrations to extract polar compounds, whereas pure carbon dioxide is useful in the extraction of non-polar to slightly polar compounds. Ethanol is recognized safe, with low environmental impact, and due it is low toxicity it is currently used in food and nutraceutical extraction processes [30-32]. According Monrad et al. [33], and Santos et al. [34], a lower concentration of ethanol cosolvent allows obtaining a higher yield of extractives. Still, a wide concentration range of the ethanol cosolvent was examined for assessing its effect on the yield of the extractives. The maximum value of ethanol was limited to its affordable concentration (96.6\%). Regarding the maximum and minimum values of pressure (1050-9000 psi), they were established according to the limits of the equipment. The particle size of the matrix also has an important impact on the overall extraction efficiency. The particle size of spruce bark in the range 1-1.4 mm, as used for the experiment, was determined based on our previous research $[23,35]$. The obtained results have shown that, to achieve a higher yield, particle size should be greater than $0.3 \mathrm{~mm}$ and smaller than $2 \mathrm{~mm}$. In this respect, it has been established that the surface area increases as the particle size decreases, due to better solute-solvent interaction [36]. A particle size greater than $2 \mathrm{~mm}$ offers a smaller surface area for mass transfer, compared with a particle size smaller than $2 \mathrm{~mm}$. On the other hand, a particle size smaller than $0.3 \mathrm{~mm}$ leads to lower yield of extractives because of particle can agglomerated in an extractor [37].

Table 1. The experimental design conditions.

\begin{tabular}{ccccccc}
\hline \multirow{2}{*}{ Name of Factors } & \multirow{2}{*}{ Factors } & $\mathbf{- 1 . 6 8 2}$ & $\mathbf{- 1}$ & $\mathbf{0}$ & $\mathbf{1}$ & $\mathbf{1 . 6 8 2}$ \\
\hline Temperature $\left({ }^{\circ} \mathbf{C}\right)$ & $\mathrm{x}_{1}$ & 40 & 52 & 70 & 88 & 100 \\
\hline Cosolvent concentration $(\%)$ & $\mathrm{x}_{2}$ & 40.0 & 51.5 & 68.3 & 85.1 & 96.6 \\
\hline Pressure (psi) & $\mathrm{x}_{3}$ & 1050 & 2660 & 5025 & 7390 & 9000 \\
\hline
\end{tabular}


Table 2. Coded and real values of design of experiment (DOE).

\begin{tabular}{|c|c|c|c|c|c|c|c|c|c|}
\hline \multirow{2}{*}{ Run } & \multicolumn{3}{|c|}{ Coded Levels of Factors } & \multicolumn{3}{|c|}{ Real Levels of Factors } & \multirow[b]{2}{*}{$\begin{array}{l}\text { YE } \\
(\%)\end{array}$} & \multirow[b]{2}{*}{ TPC $^{a}$} & \multirow[b]{2}{*}{ TEAC $^{b}$} \\
\hline & $\mathrm{x}_{1}$ & $\mathrm{x}_{2}$ & $x_{3}$ & $\begin{array}{c}t \\
\left({ }^{\circ} \mathrm{C}\right)\end{array}$ & $\begin{array}{c}c \\
(\%)\end{array}$ & $\underset{(p s i)}{p}$ & & & \\
\hline 1 & -1 & -1 & -1 & 52.16 & 51.47 & 2661.74 & 7.78 & 6.61 & 0.75 \\
\hline 2 & 1 & -1 & -1 & 87.84 & 51.47 & 2661.74 & 6.68 & 4.41 & 0.75 \\
\hline 3 & -1 & 1 & -1 & 52.16 & 85.13 & 2661.74 & 4.14 & 9.22 & 0.71 \\
\hline 4 & 1 & 1 & -1 & 87.84 & 85.13 & 2661.74 & 4.94 & 8.46 & 0.74 \\
\hline 5 & -1 & -1 & 1 & 52.16 & 51.47 & 7388.26 & 7.80 & 5.82 & 0.74 \\
\hline 6 & 1 & -1 & 1 & 87.84 & 51.47 & 7388.26 & 9.20 & 5.24 & 0.79 \\
\hline 7 & -1 & 1 & 1 & 52.16 & 85.13 & 7388.26 & 3.73 & 9.23 & 0.75 \\
\hline 8 & 1 & 1 & 1 & 87.84 & 85.13 & 7388.26 & 3.99 & 8.46 & 0.69 \\
\hline 9 & $-\alpha$ & 0 & 0 & 40.00 & 68.30 & 5025.00 & 3.78 & 7.39 & 0.76 \\
\hline 10 & $\alpha$ & 0 & 0 & 100.00 & 68.30 & 5025.00 & 4.54 & 4.47 & 0.75 \\
\hline 11 & 0 & $-\alpha$ & 0 & 70.00 & 40.00 & 5025.00 & 5.70 & 10.32 & 0.76 \\
\hline 12 & 0 & $\alpha$ & 0 & 70.00 & 96.60 & 5025.00 & 2.15 & 9.61 & 0.70 \\
\hline 13 & 0 & 0 & $\alpha$ & 70.00 & 68.30 & 1050.00 & 7.82 & 11.30 & 0.74 \\
\hline 14 & 0 & 0 & $\alpha$ & 70.00 & 68.30 & 9000.00 & 6.99 & 5.46 & 0.75 \\
\hline 15 & 0 & 0 & 0 & 70.00 & 68.30 & 5025.00 & 8.14 & 6.24 & 0.74 \\
\hline 16 & 0 & 0 & 0 & 70.00 & 68.30 & 5025.00 & 8.69 & 6.40 & 0.74 \\
\hline 17 & 0 & 0 & 0 & 70.00 & 68.30 & 5025.00 & 8.71 & 6.50 & 0.75 \\
\hline 18 & 0 & 0 & 0 & 70.00 & 68.30 & 5025.00 & 8.70 & 6.10 & 0.74 \\
\hline 19 & 0 & 0 & 0 & 70.00 & 68.30 & 5025.00 & 8.19 & 6.34 & 0.73 \\
\hline 20 & 0 & 0 & 0 & 70.00 & 68.30 & 5025.00 & 8.67 & 6.83 & 0.74 \\
\hline
\end{tabular}

$-\alpha=-1.682, \alpha=1.682,{ }^{a}$ TPC in mg GAE/g dry extract; ${ }^{\mathrm{b}}$ TEAC in $\mu \mathrm{M} \mathrm{TE} / \mathrm{mg}$ dry extract. 


\subsection{Yield of Extractives}

The general equation describing the yield of extractives as a function of the variables is shown in Equation (2).

$$
Y E=b_{0}+b_{1} x_{1}+b_{2} x_{2}+b_{3} x_{3}+b_{12} x_{1} x_{2}+b_{13} x_{1} x_{3}+b_{23} x_{2} x_{3}+b_{11} x_{12}+b_{22} x_{22}+b_{33} x_{32}
$$

Tables 3 and 4 present the results obtained by ANOVA analysis.

Table 3. Analysis of variance for yield of extractives.

\begin{tabular}{cccccc}
\hline Source of Variability & $\mathbf{s}$ & $\mathbf{f}$ & $\mathbf{s}^{\wedge} \mathbf{2}$ & $\mathbf{F}$ & $\mathbf{F}_{\mathbf{c}}$ \\
\hline $\mathrm{s}_{1}$ & 29.89 & 3 & 9.96 & 133.01 & 5.41 \\
$\mathrm{~s}_{2}$ & 51.84 & 6 & 8.64 & 115.34 & 4.95 \\
$\mathrm{~S}_{\mathrm{E}}$ & 0.37 & 5 & 0.07 & 1.00 & - \\
$\mathrm{S}_{\mathrm{LF}}$ & 6.76 & 5 & 1.35 & 18.05 & 5.05 \\
\hline
\end{tabular}

Table 4. Regression analysis for yield of extractives and total phenolics content.

\begin{tabular}{ccccc}
\hline \multirow{2}{*}{ Coefficients } & \multicolumn{2}{c}{ Yield of Extractives $(\%)$} & \multicolumn{2}{c}{ TPC (mg GAE/g Dry Extract) } \\
& $\mathbf{b}_{\mathbf{i}}$ & $\mathbf{b}_{\mathbf{c}}$ & $\mathbf{b}_{\mathbf{i}}$ & $\mathbf{b}_{\mathbf{c}}$ \\
\hline $\mathrm{b}_{0}$ & 8.49 & 0.29 & 6.30 & 0.32 \\
$\mathrm{~b}_{1}$ & 0.25 & 0.19 & -0.67 & 0.21 \\
$\mathrm{~b}_{2}$ & -1.46 & 0.19 & 0.89 & 0.21 \\
$\mathrm{~b}_{3}$ & -0.07 & 0.19 & -0.68 & 0.21 \\
$\mathrm{~b}_{11}$ & -1.33 & 0.19 & -0.33 & 0.20 \\
$\mathrm{~b}_{12}$ & 0.00 & 0.25 & 0.16 & 0.27 \\
$\mathrm{~b}_{13}$ & 0.33 & 0.25 & 0.20 & 0.27 \\
$\mathrm{~b}_{22}$ & -1.42 & 0.19 & 1.10 & 0.20 \\
$\mathrm{~b}_{23}$ & -0.4 & 0.25 & -0.004 & 0.27 \\
$\mathrm{~b}_{33}$ & -0.19 & 0.19 & 0.49 & 0.20 \\
\hline
\end{tabular}

The statistically significant regression coefficients are pointed in bold $b_{c}-$ The critical value of the coefficient on $95 \%$ probabilistic level.

According to the results obtained, both linear parameters $b_{1}$ and $b_{2}$ and both interaction parameters $b_{11}$ and $b_{22}$ strongly influenced the yield of extractives. Figure 1 shows the response surface of the yield of extractives for temperature and cosolvent concentration. The response surface passed through the global maximum. In this case, it is interesting that the lowest cosolvent concentration led to a higher value of yield of extractives compared to $\mathrm{YE}$, which was achieved by the highest cosolvent concentration. These findings are in agreement with those reported in previous investigations [33,34]. This behavior proves the significant role of the cosolvent polarity, also confirmed by our regression analysis results, which indicated that the linear terms of cosolvent concentration played the main role in the system. In Figure 1, the strong interaction for both factor at medium temperature and at medium cosolvent concentration is shown. This effect is explained by the dissolution of valuable compounds in the system. An increase in the temperature caused a decrease in the surface tension and viscosity of the system, increasing the hydrophilicity of target analytes, hence the dissolving power was higher [38]. Thus, temperature was evaluated to be the second most important factor influencing the yield of extractives, as can be noted in Table 4. Higher temperature stimulated the diffusion of carbon dioxide and the fluidity of the membrane increased. It improved the isolation of cellular material from the cells [39-41]. However, overly high temperature can lead to sample agglomeration. The yield of extractives at the highest temperature $\left(100^{\circ} \mathrm{C}, 68.3 \%, 5025 \mathrm{psi}\right)$ used in this study was $4.54 \%$, which is twice lower compared to that reached at the temperature of $70{ }^{\circ} \mathrm{C}(68.3 \%, 5025 \mathrm{psi}, \mathrm{YE}=8.7 \%)$. The results listed in Figure 1 also point out that the amount of ethanol was a significant parameter. 
In fact, its effect was more important than that of increasing the temperature by several degrees Celsius. Ethanol enhanced the yield of extractives more than twofold.

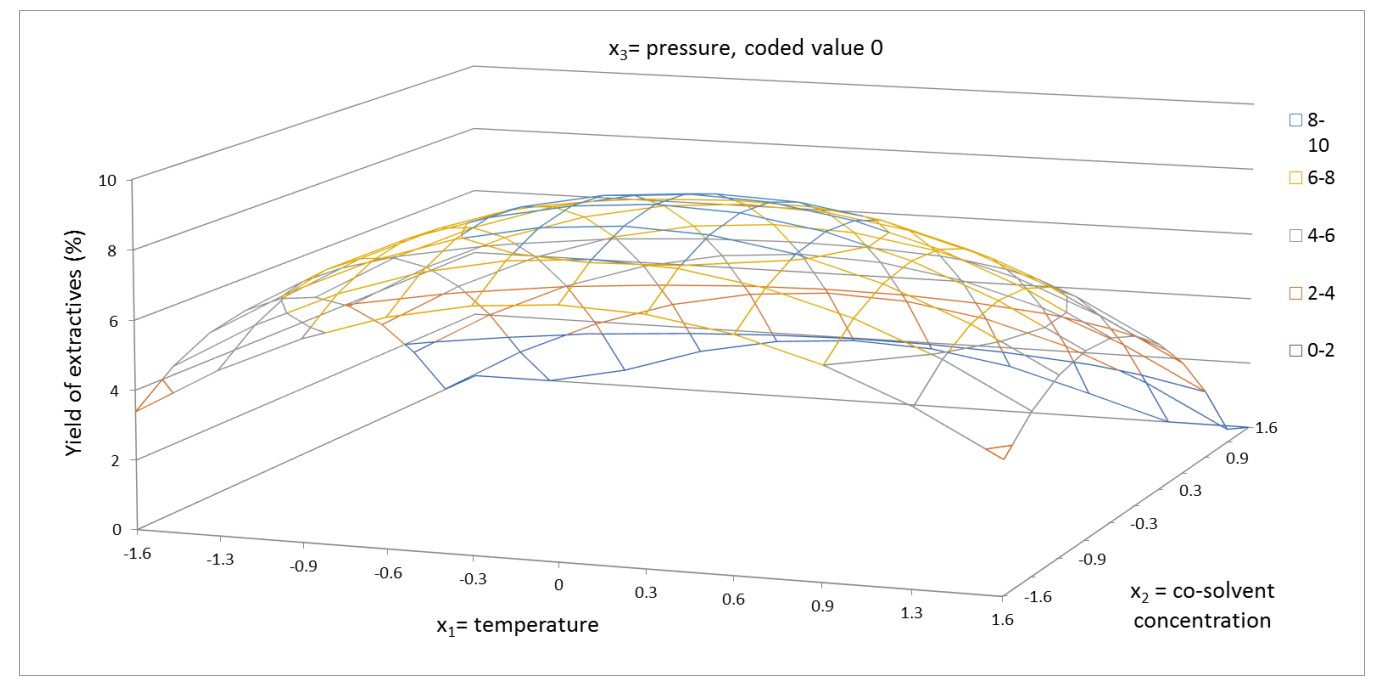

Figure 1. Response surface of extractives yield (\%) as a function of temperature in range of $40-100{ }^{\circ} \mathrm{C}$ and cosolvent concentration of $40-96.6 \% \mathrm{EtOH} /$ water, in coded values, at constant pressure of 5025 psi (coded value 0 ).

The response surface for the yield of extractives of cosolvent concentration and pressure is shown in coded values from -1.681 to +1.681 (Figures $2-4$ ). In these figures, the synergic effect between cosolvent concentration and pressure is shown. As can be seen, at temperature $100{ }^{\circ} \mathrm{C}$, the yield of extraction increased with increasing pressure, but at temperature $40^{\circ} \mathrm{C}$, the yield of extractives decreased with increasing pressure. The pressure as a single factor has been evaluated as factor with minor positive effect on the yield of extractives. In addition to the linear term of pressure, the quadratic term $b_{22}$ had a minor effect on the system. The synergic effect between temperature and pressure, as shown in Figure 5, was also confirmed.

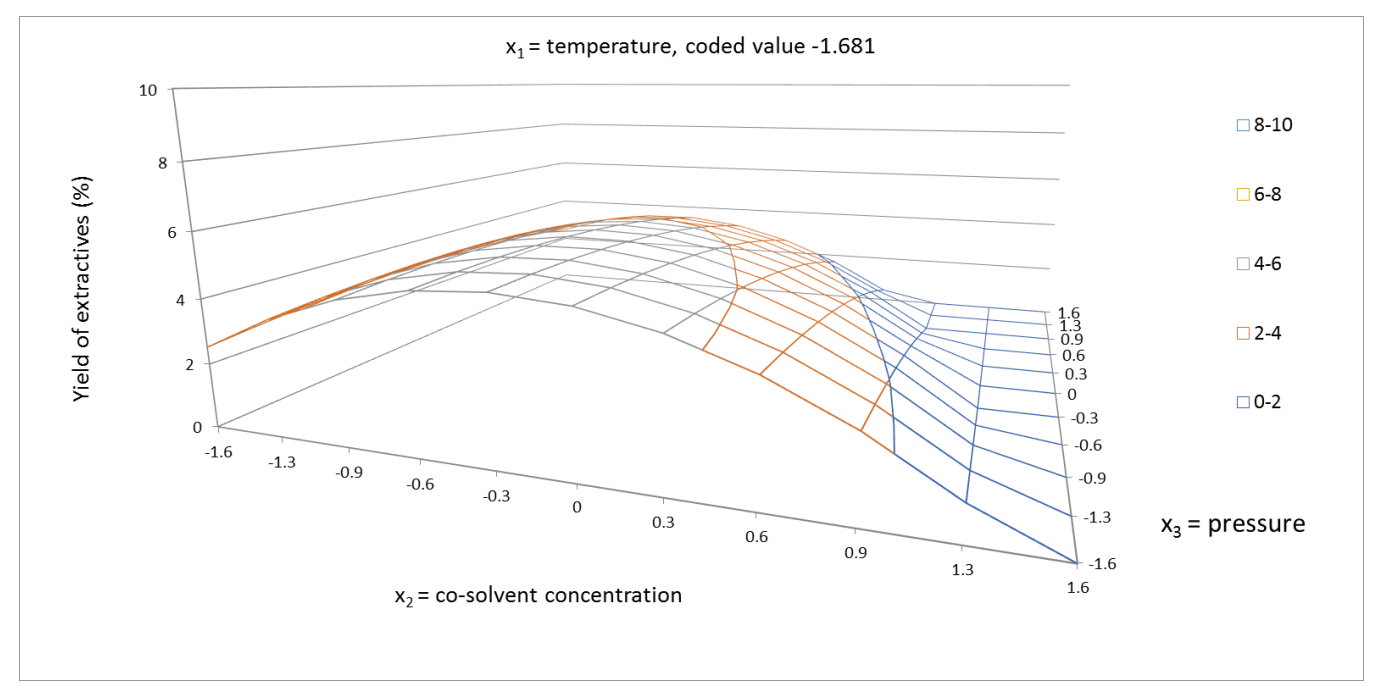

Figure 2. Response surface of extractives yield (\%) as a function of cosolvent concentration of 40-96.6\% $\mathrm{EtOH} /$ water and pressure in the range of 1050-9000 psi, in coded values, at constant temperature of $70{ }^{\circ} \mathrm{C}$ (coded value -1.681 ). 


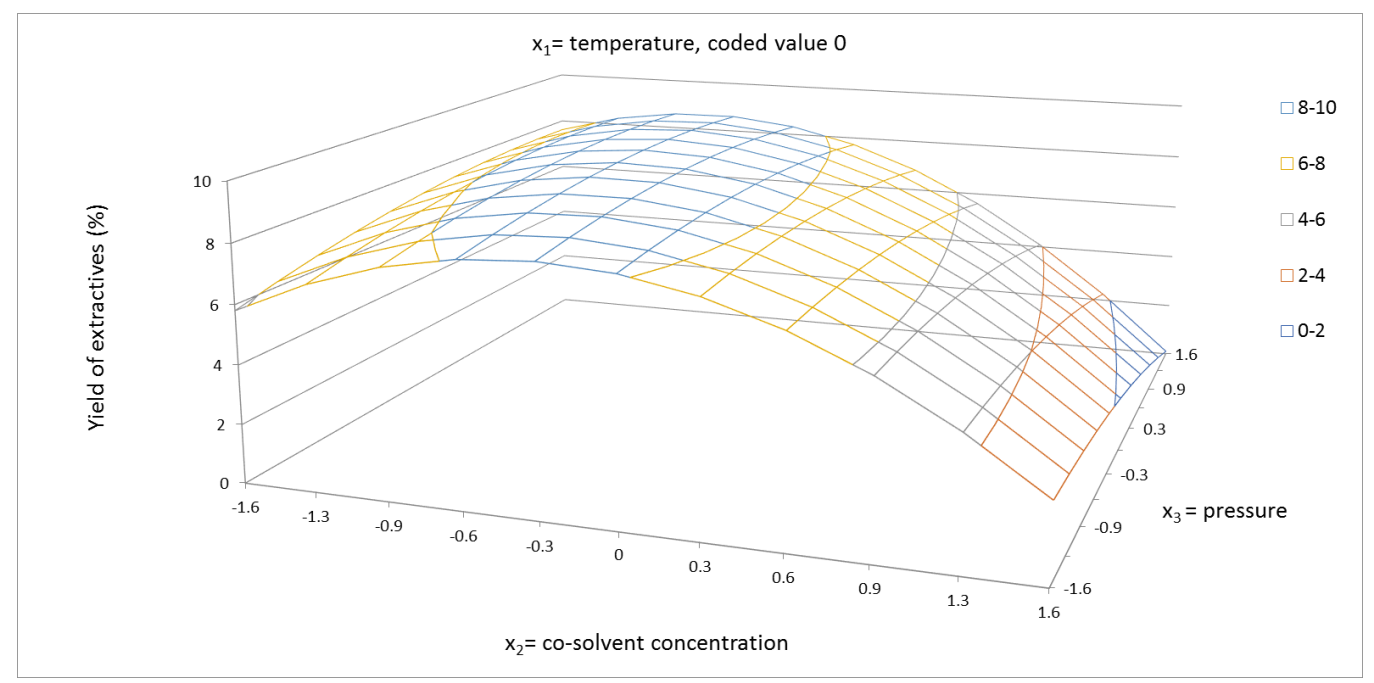

Figure 3. Response surface of extractives yield (\%) as a function of cosolvent concentration of 40-96.6\% $\mathrm{EtOH} /$ water and pressure in the range of 1050-9000 psi, in coded values, at constant temperature of $70{ }^{\circ} \mathrm{C}$ (coded value 0$)$.

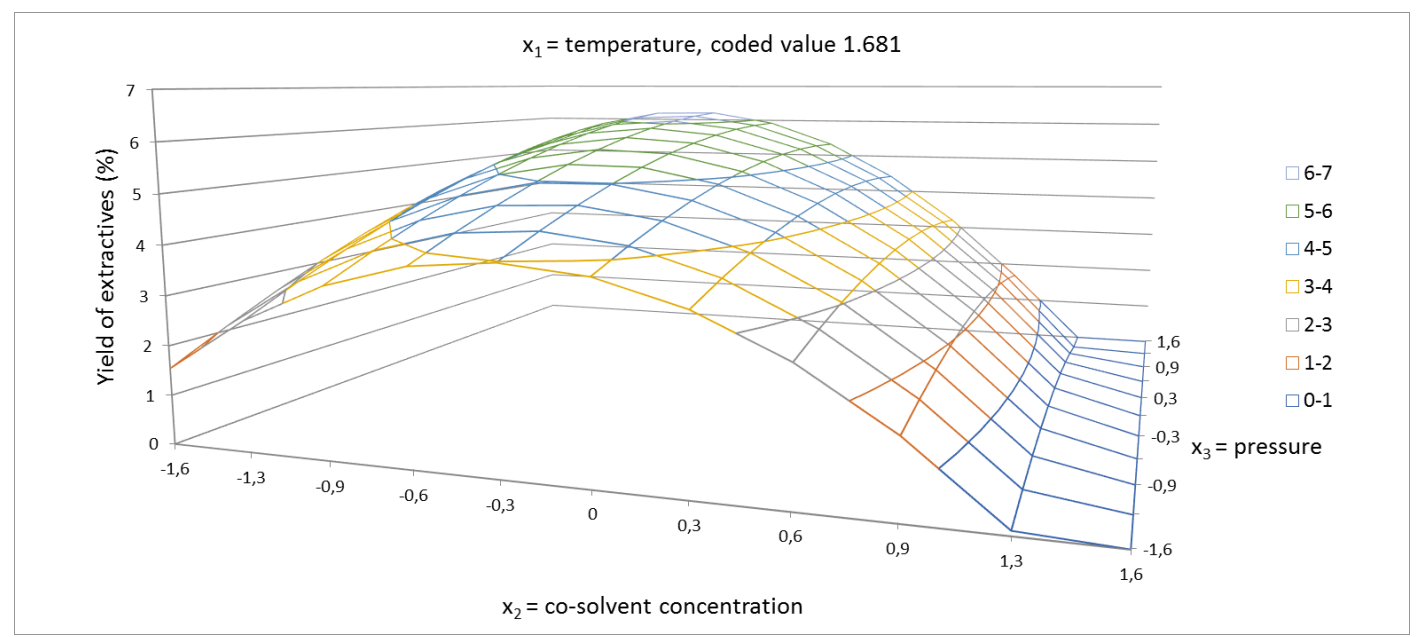

Figure 4. Response surface of extractives yield (\%) as a function of cosolvent concentration of 40-96.6\% $\mathrm{EtOH} /$ water and pressure in the range of 1050-9000 psi, in coded values, at constant temperature of $70{ }^{\circ} \mathrm{C}$ (coded value +1.681$)$. 


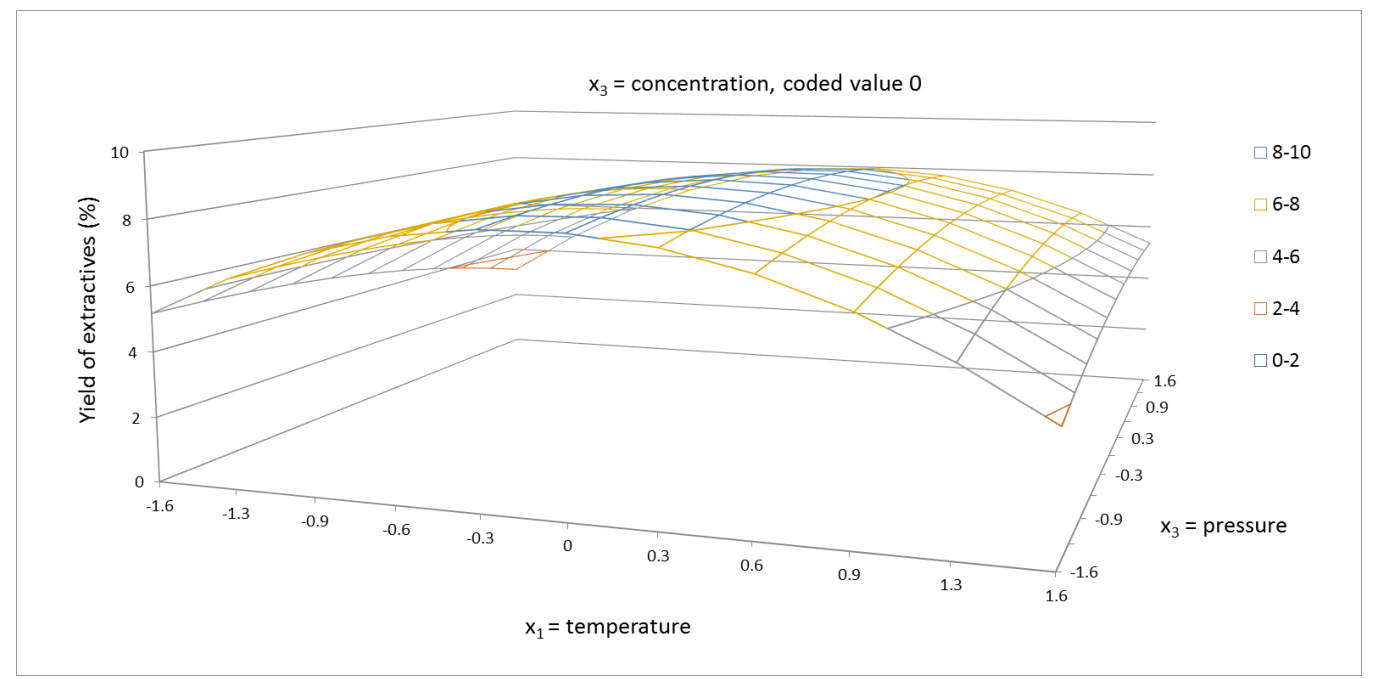

Figure 5. Response surface of extractives yield (\%) as a function of temperature, in the range of $40-100{ }^{\circ} \mathrm{C}$ and pressure in the range of 1050-9000 psi, in coded values, at constant EtOH/water cosolvent concentration of $68.3 \%$ (coded value 0 ).

\subsection{Total Phenolics Content and Antioxidant Capacity of Extracts}

Phenolic compounds represent a large group of molecules with a variety of functions in plants. Some are used as antioxidants to prevent the oxidation of fatty acids. The ability of an antioxidant to scavenge DPPH radicals is attributed to their hydrogen donating ability [42,43]. Total phenolics content was evaluated using a calibration curve obtained with gallic acid and expressed in $\mathrm{mg}$ GAE/g dry extract. The regression equation from the standard curve was $y=0.142 x+0.0142\left(R^{2}=0.9994\right)$. The antioxidant capacity of the extracts was quantified using a calibration curve obtained with Trolox. The regression equation from standard curve was $y=-0.0099 x+0.8607\left(R^{2}=0.9947\right)$. The obtained data for TPC and the antioxidant capacity were determined for each sample and the results are presented in Table 2. As can be seen, the total phenolics content of the extracts was in the range of $4.41-11.03 \mathrm{mg} \mathrm{GAE} / \mathrm{g}$ dry extract and the antioxidant capacity was in the range of $0.68-0.79 \mu \mathrm{M} \mathrm{TE} / \mathrm{mg}$ dry extract. The visualization of the effect of working parameters on total phenolics content, using 3D response surface plots, is presented in Figures 6-8. In this case, based on the ANOVA results in Table 4, the linear terms of all the independent variables had a positive effect on TPC. From the highest to the lowest, the influencing parameters were ranked in the following order: Cosolvent concentration, temperature, and pressure. According to the results, the interaction of factors, namely, cosolvent concentration-pressure, also exerted a strong influence on total phenolics content. The other interaction of factors had a minor effect on TPC. Cosolvent concentration was confirmed to have the main effect on the system, with temperature having the other significant effect. The response surface of TPC as a function of temperature and cosolvent concentration at a constant pressure $5025 \mathrm{psi}$ is shown in Figure 6. According to the results obtained, using lower temperature gives higher total phenolics content. At the temperature $100^{\circ} \mathrm{C}$, total phenolics content of $4.47 \mathrm{mg}$ GAE/g dry extract was reached, which is about $2.9 \mathrm{mg}$ lower than that achieved at the temperature of $40{ }^{\circ} \mathrm{C}(7.38 \mathrm{mg} \mathrm{GAE} / \mathrm{g}$ dry extract). These results can be attributed to the thermal degradation of polyphenols using higher temperature. According to the literature [44], rutin degrades sharply above to $100{ }^{\circ} \mathrm{C}$. Figure 8 shows the interaction between cosolvent concentration and pressure. Both factors showed a strong interaction at high co-solvent concentration and at high pressure, as well as at high cosolvent concentration and low pressure. In addition, the relationship between TPC and TEAC was discussed. From the obtained result, the correlation between TPC and TEAC was not found, since the temperature has a significant effect on the stability of polyphenols and their biological activities. According to the literature [44], 
the degradation of flavonoids depends on structural solidity and the modifications of structure of polyphenols lead to changes in antioxidant capacity.

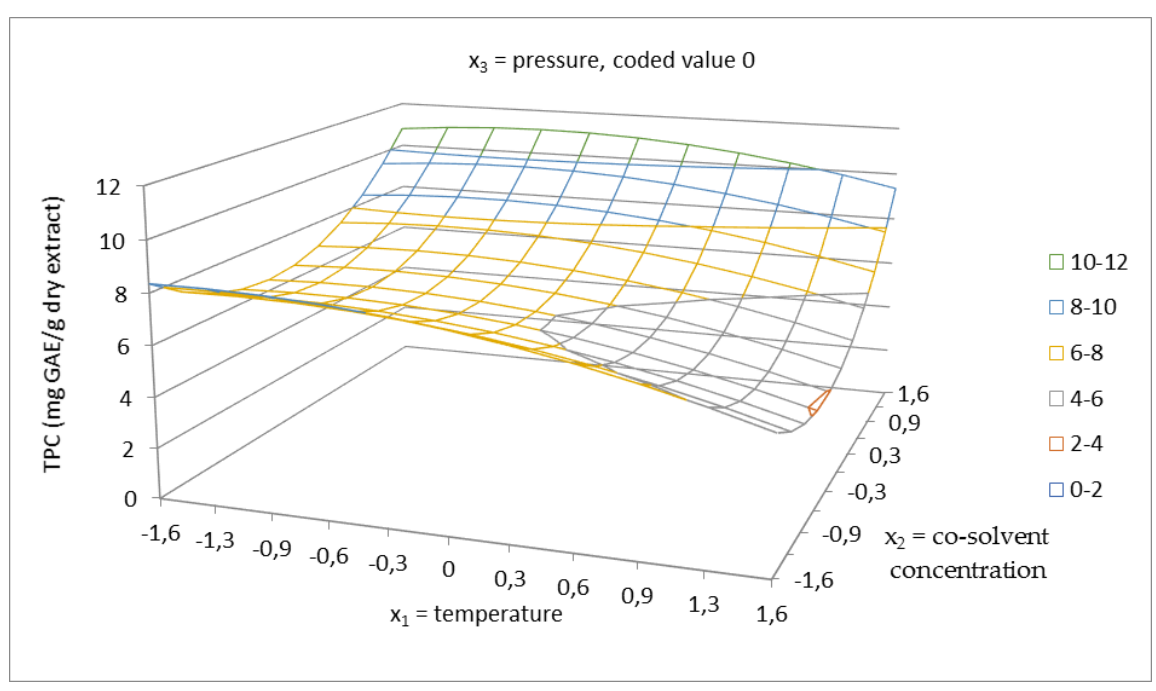

Figure 6. Response surface of total phenolics content as a function of temperature in the range of $40-100{ }^{\circ} \mathrm{C}$ and $\mathrm{EtOH} /$ water cosolvent concentration of $40-96.6 \%$ in coded values at constant pressure of 5025 psi (coded value 0 ).

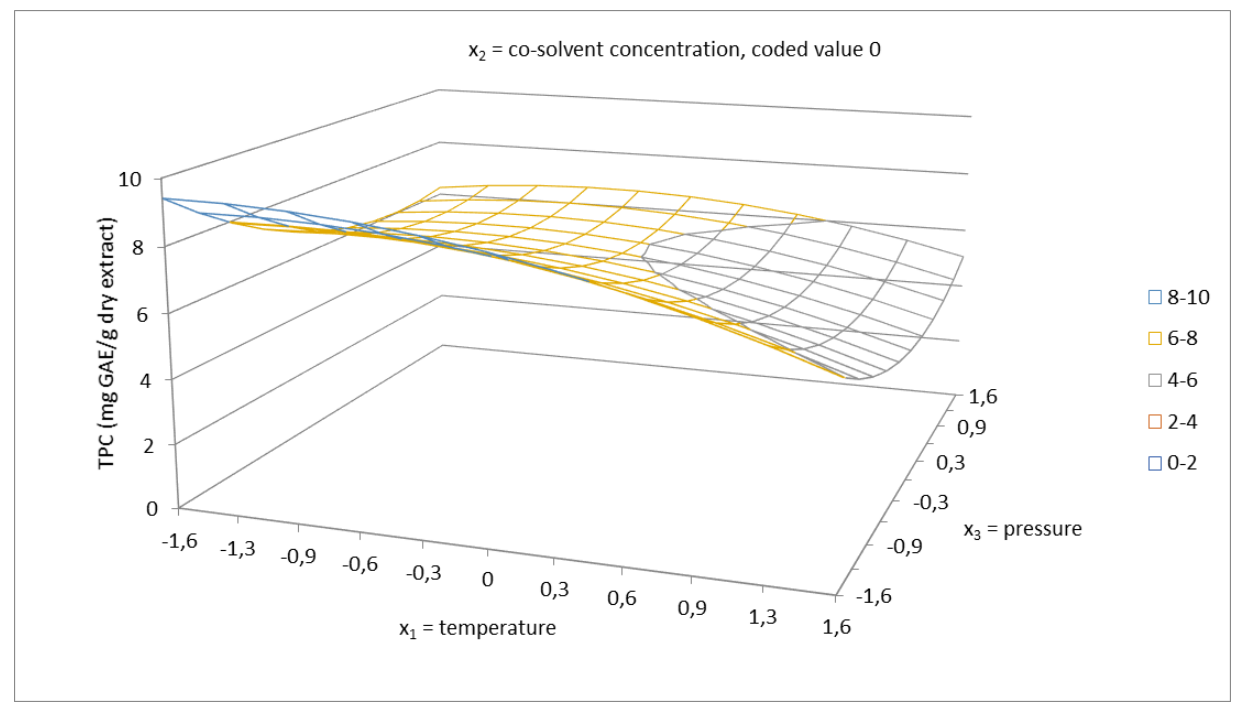

Figure 7. Response surface of total phenolics content as a function of temperature in the range of $40-100{ }^{\circ} \mathrm{C}$ and pressure in the range of 1050-9000 psi in coded values at constant EtOH/water cosolvent concentration of $68.3 \%$ (coded value 0 ). 


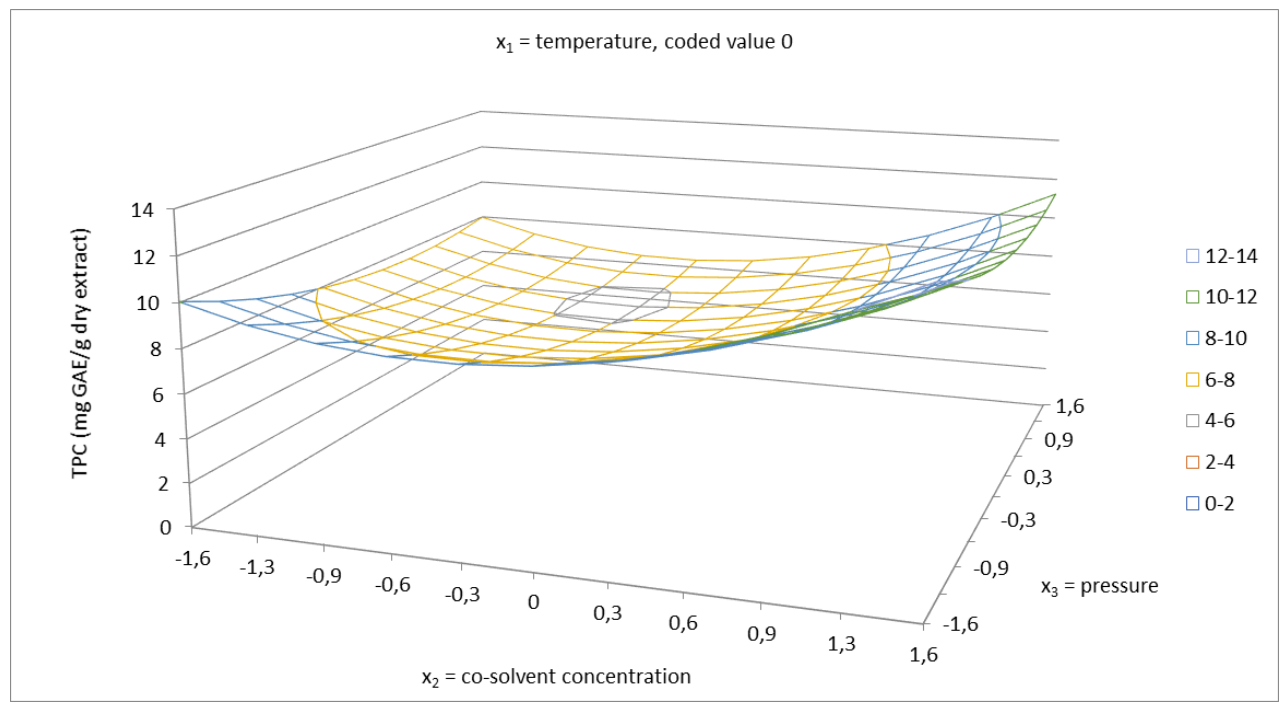

Figure 8. Response surface of total phenolics content as a function of EtOH/water cosolvent concentration of $40-96.6 \%$ and pressure in the range of 1050-9000 psi in coded values at constant temperature of $70{ }^{\circ} \mathrm{C}$ (coded value 0$)$.

\subsection{Extraction Optimization}

The operating conditions for supercritical extraction with carbon dioxide were determined in order to obtain the maximum yield of extractives. The optimal conditions for extractives yield in the ranges of the selected parameters were found as follows: $73^{\circ} \mathrm{C}, 58 \% \mathrm{EtOH} /$ water, $6465 \mathrm{psi}(44.5 \mathrm{MPa})$, for which the statistically validated regression models provided a yield of extractives of $8.92 \%$. The standard error was $\pm 0.2736 \%$. In addition, in the study, the optimum conditions for TPC were determined. According to the statistical calculations, the optimum conditions for TPC (13.89 mg GAE/g dry extract) were limited to value $45^{\circ} \mathrm{C}, 96.6 \%$, and $1050 \mathrm{psi}$, whereas the maximum value of TPC was not reached. The standard error for TPC was $\pm 0.3014 \%$.

\section{Materials and Methods}

\subsection{Chemicals}

All the reagents, standards, and solvents were of analytical grade and were purchased from Sigma-Aldrich (Saint-Louis, MO, USA), Centralchem (Bratislava, Slovak Republic), VWR International (Radnor, PA, USA), and Alfa Aesar (Haverhill, MA, USA). Carbon dioxide of 99.5\% purity was supplied by Messer Tatragas (Bratislava, Slovak Republic).

\subsection{Plant Materials}

Spruce bark (Picea abies) was provided as an industrial waste by the timber company Bioenergo Ltd. (Ruzomberok, Slovakia). The spruce bark was air-dried until a constant weight was reached, homogenized by grinding using a knife mill with a motor power of $7.5 \mathrm{~kW}$, and separated into different fractions using sieves. The spruce bark fraction of 1-1.4 mm was extracted using a supercritical extraction with carbon dioxide and analyzed to determine the content of holocellulose $(52.0 \pm 0.2 \%)$, lignin $(26.4 \pm 1.3 \%)$, ash $(3.6 \pm 0.4 \%)$, and extractives $(12.7 \pm 0.01 \%)$. The moisture content of the material $(8.77 \pm 0.08 \%)$ was determined by drying approximately $1 \mathrm{~g}$ of spruce bark at $105^{\circ} \mathrm{C}$ for $6 \mathrm{~h}$ until complete moisture removal according to ISO 3130:1975 [45]. 


\subsection{Supercritical Extraction with $\mathrm{CO}_{2}$}

The extraction was performed using a Supercritical Fluid Extractor model SFT-150 from Supercritical Fluid Technologies, Inc., Newark, NJ, USA. The schematic diagram of the SFT-150 is shown in Figure 9. Supercritical extraction has several advantages over conventional extraction techniques, e.g., the elimination of polluting organic solvents and reduced product contamination, thus being an environment-friendly, safe, fast, and cost-effective technique to yield high-purity products [36,38]. Carbon dioxide was used as supercritical fluid. As a supercritical fluid, carbon dioxide manifests higher diffusion coefficients and lower viscosities than a liquid solvent. Consequently, the diffusivity and solubility in such fluids tend to be much higher than in compared with liquids, resulting in fast reaction kinetics. Besides carbon dioxide is generally recovered as a safe, nontoxic, nonflammable, low-cost and high-purity solvent, which can easily reach supercritical conditions [46-48].

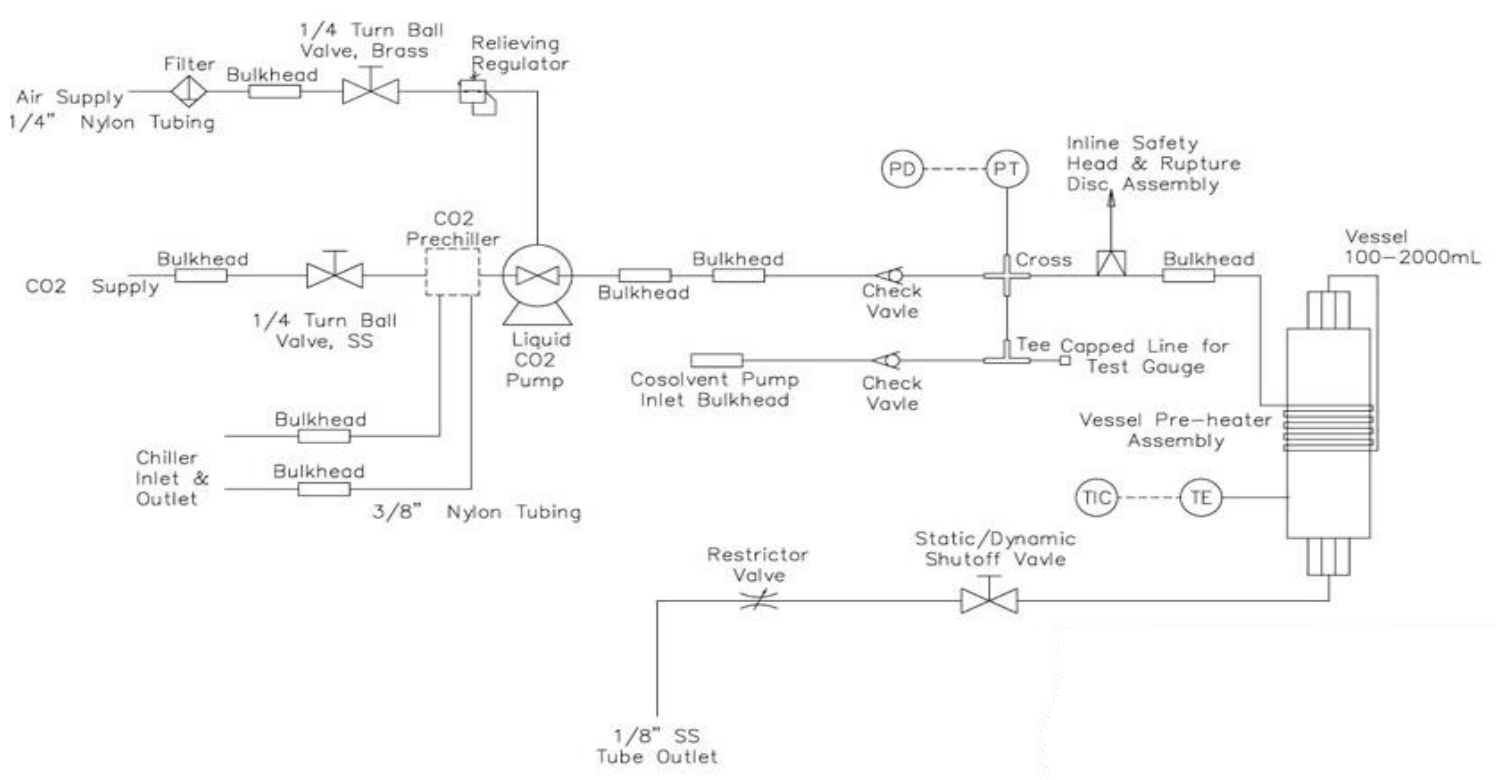

Figure 9. Diagram of supercritical extraction equipment [49].

Approximately $40 \mathrm{~g}$ of air-dried samples were filled into the extractor vessel, together with the cosolvent (mixture of ethanol and water, $\mathrm{V}=200 \mathrm{~mL}$ ). Then, the extraction conditions were set according to the Design of Experiments. The samples were extracted in the static mode with pure $\mathrm{CO}_{2}$ for $50 \mathrm{~min}$.

\subsection{Determination of Extractives Yield}

The yield of extractives (YE, \%) in each experiment was determined by drying the bark samples at $105^{\circ} \mathrm{C}$ to a constant weight. The results are expressed on the basis of the dry matter weighed before and after extraction, as shown in Equation (3):

$$
\mathrm{YE}(\%)=100 \times\left(\mathrm{m}_{\mathrm{i}}-\mathrm{m}_{\mathrm{j}}\right) / \mathrm{m}_{\mathrm{i}}
$$

where $m_{i}$ is the dry mass $(\mathrm{g})$ of the bark before extraction and $m_{j}$ is the mass $(\mathrm{g})$ of the bark after extraction and drying.

\subsection{Determination of Total Phenolics Content}

Total phenolics content (TPC) of the extracts was determined by the Folin-Ciocalteu assay, based on the redox reactions of phenolic compounds [50]. A volume of $0.5 \mathrm{~mL}$ of Folin-Ciocalteu reagent and $0.5 \mathrm{~mL}$ of the extract or ethanol (as blank sample) were pipetted into a test tube. After $3 \mathrm{~min}, 1.5 \mathrm{~mL}$ of $20 \%$ sodium carbonate solution and distilled water were added into the test tube. After stirring, 
the mixture was incubated in a closed dark colored flask at room temperature for $120 \mathrm{~min}$, and then the absorbance of the solution was recorded at $765 \mathrm{~nm}$. The TPC in the extracts was determined using the calibration curve based on the absorbance at $765 \mathrm{~nm}$ and expressed as gallic acid equivalent (GAE) in mg per $1 \mathrm{~g}$ of dry extract.

\subsection{Determination of Antioxidant Capacity}

The antioxidant activity of the extracts was determined using the Trolox equivalent antioxidant capacity (TEAC) method using 2,2-diphenyl-1-picrylhydrazyl (DPPH; $\mathrm{C}_{18} \mathrm{H}_{12} \mathrm{~N}_{5} \mathrm{O}_{6}, \mathrm{M}=394.33 \mathrm{~g} / \mathrm{mol}$ ) as a free radical Figure 10. This assay is based on the ability of the antioxidant to neutralize the DPPH radical via electron donation. The odd electron of the nitrogen atom in the DPPH radical is reduced by receiving a hydrogen atom from the antioxidant to the corresponding hydrazine. The DPPH radical produces deep purple-colored solutions. The purple color of the initial solution turns yellow when the free radical is blocked by the substance that can donate a hydrogen atom [51].

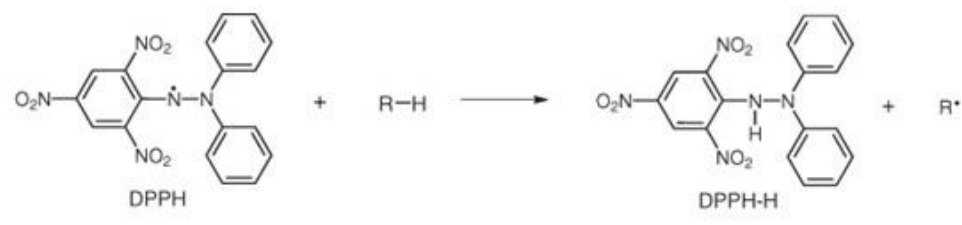

Figure 10. Reaction mechanism of 2,2-diphenyl-1-picrylhydrazyl (DPPH) radical with an antioxidant [52].

This assay was performed according to the method modified by Mareček at al. (2017) [53]. An amount of $200 \mu \mathrm{L}$ sample (1 mg of dry extract diluted in $10 \mathrm{~mL}$ of $95 \%$ ethanol), mixed with $75 \mu \mathrm{L}$ of DPPH $(0.5 \mathrm{mM}$ in $95 \%$ ethanol) or $75 \mu \mathrm{L}$ of ethanol (as blank sample), was used for the measurement at $517 \mathrm{~nm}$. It was determined by the calibration curve that the concentration of Trolox ranged from $0.5-80 \mu \mathrm{M}$. The antioxidant activity was expressed as Trolox equivalents $(\mu \mathrm{M}$ TE) on $1 \mathrm{mg}$ of dry extract.

\section{Conclusions}

Based on the analysis of the experiment, our findings lead to the conclusion that the extraction conditions have a significant impact on the extraction yield, especially the cosolvent concentration and temperature used. The cosolvent concentration had the most significant effect on the yield of extractives, followed by the temperature, while the pressure had a minimal effect on the yield of extractives. Higher temperature enabled an easier passage of the target analytes through the pores on the surface of the natural matrix. The use of ethanol and water as SFE modifier is suitable to extract a significant share of valuable compounds from spruce bark, containing of polyphenols, which were found to exhibit antioxidant capacity. Results also reveal that the antioxidant capacity of the spruce bark extract cannot be defined solely its total phenolics content. Therefore, the antioxidant properties depend on the sample and differ among the phenolic compounds. Moreover, the amount of all the phenolics occurring in spruce bark still remains unknown, requiring further detailed studies.

Author Contributions: P.S. and Z.B. contributed equally to the conceptualization and design of the work; writing-Original draft preparation: P.S.; data curation: A.H., J.F.; supervision and critical revision of the manuscript: P.S., M.J., I.Š., F.K.; project administration: I.Š., F.K.; funding acquisition: M.J., I.Š., Z.B. All of the authors approved the version of the manuscript submitted for publication.

Funding: This work was supported by the Slovak Research and Development Agency under the contracts Nos. APVV-15-0052, APVV-0393-14, APVV-16-0088 and VEGA 1/0403/19. This article was realized also thanks to the support for infrastructure equipment provided by the Operation Program Research and Development for the project "National Center for Research and Application of renewable energy sources" (ITMS 26240120016, ITMS 26240120028), for the project "Competence center for new materials, advanced technologies and energy" (ITMS 26240220073), and for the project “University science park STU Bratislava" (ITMS 26240220084), co-financed by the European Regional Development Fund. The authors would like to thank the STU Grant Scheme for Support of Excellent Teams of Young Researchers for financial assistance under contracts no.1671. 
Acknowledgments: The authors would like to acknowledge the financial support of the Slovak Research and Development Agency and support for infrastructure equipment provided by the Operation Program Research and Development.

Conflicts of Interest: The authors declare no conflict of interest. The funders had no role in the design of the study; in the collection, analyses, or interpretation of data; in the writing of the manuscript, or in the decision to publish the results.

\section{References}

1. Kemppainen, K.; Siika-aho, M.; Pattathil, S.; Giovando, S. Spruce bark as an industrial source of condensed tannins and non-cellulosic sugars. Ind. Crops Prod. 2014, 52, 158-168. [CrossRef]

2. Harkin, J.M.; Rowe, J.W. United States Forest Service research note Forest Products Laboratory. Available online: https://www.fpl.fs.fed.us/documnts/fplrn/fplrn091.pdf (accessed on 8 August 2019).

3. Miranda, I.; Gominho, J.; Mirra, I.; Pereira, H. Chemical characterization of barks from Picea abies and Pinus sylvestris after fractioning into different particle sizes. Ind. Crops Prod. 2012, 36, 395-400. [CrossRef]

4. Räisänen, T.; Athanassiadis, D. Semanticscholar. Available online: https://www.semanticscholar.org/ paper/Basic-chemical-composition-of-the-biomass-of-pine\%2C-R\%C3\%A4is\%C3\%A4nen-Athanassiadis/ f17423a8129685dd0a874ad47d16431862505d7b (accessed on 7 August 2019).

5. Pietarinen, S.P.; Willför, S.M.; Ahotupa, M.O.; Hemming, J.E.; Holmbom, B.R. Knotwood and bark extracts: Strong antioxidants from waste materials. J. Wood Sci. 2006, 52, 436-444. [CrossRef]

6. Conde, E.; Cadahia, E.; Diez-Barra, R.; García-Vallejo, M. Polyphenolic composition of bark extracts fromEucalyptus camaldulensis, E. globulus and E. rudis. Holz als Roh-und Werkstoff 1996, 54, 175-181. [CrossRef]

7. Şen, A.; Miranda, I.; Santos, S.; Graça, J.; Pereira, H. The chemical composition of cork and phloem in the rhytidome of Quercus cerris bark. Ind. Crops Prod. 2010, 31, 417-422. [CrossRef]

8. Valentín, L.; Kluczek-Turpeinen, B.; Willför, S.; Hemming, J.; Hatakka, A.; Steffen, K.; Tuomela, M. Scots pine (Pinus sylvestris) bark composition and degradation by fungi: Potential substrate for bioremediation. Bioresour. Technol. 2010, 101, 2203-2209. [CrossRef]

9. Tsao, R.J.N. Chemistry and biochemistry of dietary polyphenols. Nutrients 2010, 2, 1231-1246. [CrossRef]

10. Ozcan, T.; Akpinar-Bayizit, A.; Yilmaz-Ersan, L.; Delikanli. Phenolics in human health. Int. J. Chem. Eng. Appl. 2014, 5, 393.

11. Nascimento, M.; Santana, A.; Maranhão, C.; Oliveira, L.; Bieber, L. Phenolic extractives and natural resistance of wood. In Biodegradation-Life of Science; Chamy, R., Rosenkranz, F., Eds.; InTech: Rijeka, Croatia, 2013; pp. 349-370.

12. Laurova, M.; Vybohova, E.; Mamonova, M. Heartwood and Sapwood Liphophilic Extractives of Oak (Quercus petraea (Mattusch.) Liebl.). Acta Facultatis-Xylologiae 2007, 2, 17.

13. Jablonsky, M.; Nosalova, J.; Sladkova, A.; Haz, A.; Kreps, F.; Valka, J.; Miertus, S.; Frecer, V.; Ondrejovic, M.; Sima, J.J.B.a. Valorisation of softwood bark through extraction of utilizable chemicals. A review. Biotechnol. Adv. 2017, 35, 726-750. [CrossRef]

14. Caron, A.; Altaner, C.M.; Gardiner, B.; Jarvis, M.C. Distribution of extractives in Sitka spruce (Picea sitchensis) grown in the northern UK. Eur. J. Wood Wood Prod. 2013, 71, 697-704. [CrossRef]

15. Hon, D.N.-S.; Shiraishi, N. Wood and cellulosic chemistry, revised, and expanded; Marcel Dekker: New York, NY, USA, 2000; Chapter 7.

16. Kanadaswami, C.; Lee, L.; Lee, P.; Hwang, J.; Ke, F.; Huang, Y.; Lee, M. The antitumor activities of flavonoids. In Vivo 2005, 19, 895-909.

17. Middleton, E.; Kandaswami, C.; Theoharides, T.C. The effects of plant flavonoids on mammalian cells: Implications for inflammation, heart disease, and cancer. Pharmacol. Rev. 2000, 52, 673-751. [PubMed]

18. Ghitescu, R.-E.; Volf, I.; Carausu, C.; Bühlmann, A.-M.; Gilca, I.A.; Popa, V.I. Optimization of ultrasound-assisted extraction of polyphenols from spruce wood bark. Ultrason. Sonochem. 2015, 22, 535-541. [CrossRef]

19. Lazar, L.; Talmaciu, A.I.; Volf, I.; Popa, V.I. Kinetic modeling of the ultrasound-assisted extraction of polyphenols from Picea abies bark. Ultrason. Sonochem 2016, 32, 191-197. [CrossRef]

20. Talmaciu, A.I.; Volf, I.; Popa, V.I. Supercritical Fluids and Ultrasound Assisted Extractions Applied to Spruce Bark Conversion. Environ. Eng. Manage. J. 2015, 14, 615-623. 
21. Co, M.; Fagerlund, A.; Engman, L.; Sunnerheim, K.; Sjöberg, P.J.; Turner, C. Extraction of antioxidants from spruce (Picea abies) bark using eco-friendly solvents. Phytochem. Anal. 2012, 23, 1-11. [CrossRef]

22. Bouras, M.; Chadni, M.; Barba, F.J.; Grimi, N.; Bals, O.; Vorobiev, E. Products. Optimization of microwave-assisted extraction of polyphenols from Quercus bark. Ind. Crops Prod. 2015, 77, 590-601. [CrossRef]

23. Sládková, A.; Benedeková, M.; Stopka, J.; Šurina, I.; Ház, A.; Strižincová, P.; Čižová, K.; Škulcová, A.; Burčová, Z.; Kreps, F. Yield of polyphenolic substances extracted from spruce (Picea abies) bark by microwave-assisted extraction. BioResources 2016, 11, 9912-9921. [CrossRef]

24. Jablonsky, M.; Vernarecová, M.; Ház, A.; Dubinyová, L.; Skulcova, A.; Sladková, A.; Surina, I.J. Extraction of phenolic and lipophilic compounds from spruce (Picea abies) bark using accelerated solvent extraction by ethanol. Wood Res. 2015, 60, 583-590.

25. Talmaciu, A.I.; Ravber, M.; Volf, I.; Knez, Ž.; Popa, V.I. Isolation of bioactive compounds from spruce bark waste using sub-and supercritical fluids. J. Supercrit. Fluids 2016, 117, 243-251. [CrossRef]

26. Belwal, T.; Ezzat, S.M.; Rastrelli, L.; Bhatt, I.D.; Daglia, M.; Baldi, A.; Devkota, H.P.; Orhan, I.E.; Patra, J.K.; Das, G. A critical analysis of extraction techniques used for botanicals: Trends, priorities, industrial uses and optimization strategies. TrAC Trends Anal. Chem. 2018, 100, 82-102. [CrossRef]

27. Alexy, P.; Viselka, M. STATIS Program for Planning and Evaluation of Experiments Food Technology; Department of Plastics and Rubber, Faculty of Chemical and Food Technology, SUT: Bratislava, Slovakia, 1998.

28. Destandau, E.; Michel, T.; Elfakir, C. Microwave-assisted extraction. In Natural Product Extraction: Principles and applications; RSC Publishing: Cambridge, UK, 2013; pp. 113-156.

29. Xiao, W.; Han, L.; Shi, B. Microwave-assisted extraction of flavonoids from Radix Astragali. Sep. Purif. Technol. 2008, 62, 614-618. [CrossRef]

30. Markom, M.; Hasan, M.; Daud, W.R.W.; Singh, H.; Jahim, J.; Technology, P. Extraction of hydrolysable tannins from Phyllanthus niruri Linn.: Effects of solvents and extraction methods. Sep. Purif. Technol. 2007, 52, 487-496. [CrossRef]

31. Katayama, S.; Zhao, L.; Yonezawa, S.; Iwai, Y. Modification of the surface of cotton with supercritical carbon dioxide and water to support nanoparticles. J. Supercrit. Fluids 2012, 61, 199-205. [CrossRef]

32. Leitão, N.; Prado, G.; Veggi, P.; Meireles, M.; Pereira, C. Anacardium occidentale L. leaves extraction via SFE: Global yields, extraction kinetics, mathematical modeling and economic evaluation. J. Supercrit. Fluids 2013, 78, 114-123. [CrossRef]

33. Monrad, J.K.; Howard, L.R.; King, J.W.; Srinivas, K.; Mauromoustakos, A. Subcritical solvent extraction of anthocyanins from dried red grape pomace. J. Agric. food chem. 2010, 58, 2862-2868. [CrossRef] [PubMed]

34. Santos, S.A.; Villaverde, J.J.; Silva, C.M.; Neto, C.P.; Silvestre, A.J. Supercritical fluid extraction of phenolic compounds from Eucalyptus globulus Labill bark. J. Supercrit. Fluids 2012, 71, 71-79. [CrossRef]

35. Strizincova, P.; Ház, A.; Sládková, A.; Jablonský, M.; Surina, I. Optimization conditions of extraction. In Proceedings of the FP1306 COST Action Third Workshop and Fourth MC Meeting, Torremolinos, Spain, 27-28 March 2017; p. 89.

36. Mandal, S.C.; Mandal, V.; Das, A.K. Essentials of botanical extraction: Principles and applications, 1st ed.; Academic Press: Cambridge, MA, USA, 2015.

37. Baldosano, H.Y.; Castillo, M.B.M.G.; Elloran, C.D.H.; Bacani, F.T. Effect of particle size, solvent and extraction time on tannin extract from Spondias purpurea bark through soxhlet extraction. In Proceedings of the DLSU Research Congress, De La Salle University, Manila, Philippines, 2-4 March 2015; pp. 1-6.

38. Sapkale, G.; Patil, S.; Surwase, U.; Bhatbhage, P. Supercritical fluid extraction. Int. J. Chem. Sci. 2010, $8,729-743$.

39. Garcia-Gonzalez, L.; Geeraerd, A.H.; Spilimbergo, S.; Elst, K.; Van Ginneken, L.; Debevere, J.; Van Impe, J.; Devlieghere, F. High pressure carbon dioxide inactivation of microorganisms in foods: The past, the present and the future. Int. J. Food Microbiol. 2007, 117, 1-28. [CrossRef]

40. Wimmer, Z.; Zarevúcka, M. A review on the effects of supercritical carbon dioxide on enzyme activity. Int. J. Mol. Sci. 2010, 11, 233-253. [CrossRef] [PubMed]

41. Čolnik, M.; Primožič, M.; Knez, Ž.; Leitgeb, M. Use of non-conventional cell Disruption Method for extraction of Proteins from Black Yeasts. Front. Bioeng. Biotechnol. 2016, 4, 33. [CrossRef] [PubMed]

42. Liu, J.; Jia, L.; Kan, J.; Jin, C.-H. In vitro and in vivo antioxidant activity of ethanolic extract of white button mushroom (Agaricus bisporus). Food chem. Toxicol. 2013, 51, 310-316. [CrossRef] [PubMed] 
43. Kraujalis, P.; Venskutonis, P.R.; Ibáñez, E.; Herrero, M. Optimization of rutin isolation from Amaranthus paniculatus leaves by high pressure extraction and fractionation techniques. J. Supercrit. Fluids 2015, 104, 234-242. [CrossRef]

44. Chaaban, H.; Ioannou, I.; Chebil, L.; Slimane, M.; Gérardin, C.; Paris, C.; Charbonnel, C.; Chekir, L.; Ghoul, M. Effect of heat processing on thermal stability and antioxidant activity of six flavonoids. J. Food process. Preserv. 2017, 41, e13203. [CrossRef]

45. International Standard ISO. Available online: https://www.iso.org/standard/8288.html (accessed on 15 September 2019).

46. Zougagh, M.; Valcárcel, M.; Rıs, A. Supercritical fluid extraction: A critical review of its analytical usefulness. TrAC Trends Anal. Chem. 2004, 23, 399-405. [CrossRef]

47. Veggi, P.C.; Prado, J.M.; Bataglion, G.A.; Eberlin, M.N.; Meireles, M.A.A. Obtaining phenolic compounds from jatoba (Hymenaea courbaril L.) bark by supercritical fluid extraction. J. Supercrit. Fluids 2014, 89, 68-77. [CrossRef]

48. Martinez-Correa, H.A.; Magalhães, P.M.; Queiroga, C.L.; Peixoto, C.A.; Oliveira, A.L.; Cabral, F.A. Extracts from pitanga (Eugenia uniflora L.) leaves: Influence of extraction process on antioxidant properties and yield of phenolic compounds. J. Supercrit. Fluids 2011, 55, 998-1006. [CrossRef]

49. Supercritical Fluids. Available online: http://www.supercriticalfluids.com/wp-content/uploads/Spec-SheetSFT-150.pdf (accessed on 10 September 2019).

50. Yu, L.; Haley, S.; Perret, J.; Harris, M. Antioxidant properties of hard winter wheat extracts. Food chem. 2002, 78, 457-461. [CrossRef]

51. Kedare, S.B.; Singh, R. Genesis and development of DPPH method of antioxidant assay. J. Food Sci. Technol. 2011, 48, 412-422. [CrossRef]

52. Gressler, V.; Moura, S.; Flores, A.F.; Flores, D.C.; Colepicolo, P.; Pinto, E. Antioxidant and antimicrobial properties of 2-(4, 5-dihydro-1H-pyrazol-1-yl)-pyrimidine and 1-carboxamidino-1H-pyrazole derivatives. J. Braz. Chem. Soc. 2010, 21, 1477-1483. [CrossRef]

53. Mareček, V.; Mikyška, A.; Hampel, D.; Čejka, P.; Neuwirthová, J.; Malachová, A.; Cerkal, R. ABTS and DPPH methods as a tool for studying antioxidant capacity of spring barley and malt. J. Cereal Sci. 2017, 73, 40-45. [CrossRef]

Sample Availability: Samples of the compounds are not available from the authors.

(C) 2019 by the authors. Licensee MDPI, Basel, Switzerland. This article is an open access article distributed under the terms and conditions of the Creative Commons Attribution (CC BY) license (http://creativecommons.org/licenses/by/4.0/). 